\section{The improvement of early maturity red rice mutant trait for drought tolerance}

\author{
Eries D. Mustikarini, ${ }^{1}$ \\ Noer Rahmi Ardiarini, ${ }^{2}$ \\ Nur Basuki, ${ }^{2}$ Kuswanto ${ }^{2}$
}

1Department of Agrotechnology, Bangka

Belitung University, Bangka; ${ }^{2}$ Department

of Agricultural Science, Faculty of

Agriculture, Brawijaya University,

Malang, Indonesia

\begin{abstract}
Accession of red rice does not have the traits of early maturity, drought tolerance and high yield. Mutation is needed to obtain the desired genetic resources. Gamma-ray irradiation is the right method because it was proved capable of producing hundreds of new varieties, which are better than the previous. This study aimed to identify the improvement of early maturity and drought tolerance of red rice mutant to gamma ray irradiation results. The research materials are M4, M5 and M6 strain, which are derived from the Bangka's accession local red rice (Celak Madu, Ruten Puren and radix). The three accession seed have been treated with gamma-ray irradiation doses of 150, 200 and 250 Gray. The results showed gamma ray irradiation dose of 150 Gray and 200 Gray to red rice accession can form a mutant with the character of harvesting time less than 115 days after planting and was more drought tolerant than the previous. M6-GR1501-9-13 strain was selected as a candidate for early maturity, drought tolerant and high yield mutant.
\end{abstract}

\section{Introduction}

Red rice paddy has nutritional value and anthocyanin higher than white rice. The anthocyanin content of local Indonesian red rice paddy is 0.03 to $210.50 \mathrm{mg} / 100 \mathrm{~g}$ and Thai rice is $109 \mathrm{mg} / 100 \mathrm{~g} .{ }^{1,2}$ The amino acid alanine in red rice paddy turns off the function of free radicals. ${ }^{3}$ Antioxidant activity of several red rice cultivar reached $54.2 \%$ at concentration of $0.25 \mathrm{mg} / \mathrm{mL}^{4}$

Red rice paddy accession has longer time to harvest (121-138 days) with a flowering time of 91-107 days. ${ }^{5,6}$ Red rice accession is not classified as drought tolerant so it has lower yield (an average of 2 tons/ha). ${ }^{7}$ Currently, there is only one variety of red rice classified as upland types, which is Inpago 7 (4.6 tons/ha). ${ }^{8}$ The properties of early maturity and drought tolerance were controlled by quantitative genes (Hd1 to Hd14 based on QTL analysis) which influenced by environment. ${ }^{9}$ There were 413 and 245 genes found to be significantly induced and suppressed by applying gradual, long-term drought stress to four rice cultivars with differing drought resistance. ${ }^{10}$

Genetic improvement of plants could be done through physical mutation using gamma irradiation. Gamma ray irradiation dose of 200 Gray has been proved to reduce harvesting age of rice up to 65-69 days compared to the previous. ${ }^{11,12}$ Selection of gamma irradiation results are mutant strain which is more drought tolerant, has early maturity and yielding of more than 5 tons/ha. ${ }^{13}$ Gamma ray irradiation on rice seed is capable to form permanent red rice varieties and increase the genetic diversity. Stable genotypes showed positive response if it is grown in different environments. ${ }^{7}$ Drought tolerance test in rice has been done with a solution of polyethylene glycol (PEG) by reducing soil moisture and stress in rice critical phase. ${ }^{14}$ The research was aims to determine the role of gamma ray irradiation for the improvement of early maturity and drought tolerant traits of red rice mutants.

\section{Materials and Methods}

The research was conducted in ultisols (Balunijuk, Bangka Belitung, Indonesia) and it took place from November 2013 to February 2015. The plant material used was 16 of fourth mutant (M4) of red rice origin from Celak Madu accession with irradiation dose of 150 Gray $\left(\mathrm{M}_{4}-\mathrm{G}_{\mathrm{C} 150}-1, \mathrm{M}_{4}-\mathrm{G}_{\mathrm{Cl} 150}-2\right.$ and $\left.\mathrm{M}_{4}-\mathrm{G}_{\mathrm{C} 150}-3\right)$ and 250 Gray $\left(\mathrm{M}_{4}-\mathrm{G}_{\mathrm{C} 250^{-}}-1, \mathrm{M}_{4}-\mathrm{G}_{\mathrm{C} 250^{-}}-2\right.$ and $\mathrm{M}_{4}-\mathrm{G}_{\mathrm{C} 250^{-}}$ 3); Ruten Puren accession with irradiation dose of 200 gray $\left(\mathrm{M}_{4}-\mathrm{G}_{\mathrm{P} 200^{-}}-1, \mathrm{M}_{4}-\mathrm{G}_{\mathrm{P} 200^{-}}-2, \mathrm{M}_{4^{-}}\right.$ $\mathrm{G}_{\mathrm{P} 200^{-}}-3$ and $\left.\mathrm{M}_{4}-\mathrm{G}_{\mathrm{P} 200}-4\right)$ and 250 gray $\left(\mathrm{M}_{4}-\mathrm{G}_{\mathrm{P} 250^{-}}\right.$ 1); radix accession with irradiation dose of 150 gray $\left(\mathrm{M}_{4}-\mathrm{G}_{\mathrm{R} 150}-1, \mathrm{M}_{4}-\mathrm{G}_{\mathrm{R} 150}-2\right.$ and $\left.\mathrm{M}_{4}-\mathrm{G}_{\mathrm{R} 150}-3\right)$ and 200 gray $\left(\mathrm{M}_{4}-\mathrm{G}_{\mathrm{R} 200^{-}}-1\right.$ and $\left.\mathrm{M}_{4}-\mathrm{G}_{\mathrm{R} 200}-2\right)$. Those $\mathrm{M} 4$ were selected because of their early maturity at the third mutants (M3).

The first research was the selection of 1920 individual pedigree of M4 to get early maturity and high grain yield traits. Harvesting age (dap), number of productive tillers, panicle length, number of filled seeds, filled seed weight and weight of 1000 seeds were observed.

The second research was the selection of drought tolerant trait in M5 strain that has 36 mutant lines, which were selected on M4. Research activities was started with the selection of seeds in a solution of PEG $8000-0.5$ MPa for 14 days and gave 5 strain of M5 which has the highest germination. The treatments were arranged in a split-plot design such as
Correspondence: Eries D. Mustikarini, Department of Agrotechnology, Bangka Belitung University, Bangka, Indonesia.

Tel/Fax: +62.817.5254225.

E-mail: eriesdyah@yahoo.com

Key words: Drought tolerant; early maturity; gamma; mutant; red rice paddy.

Acknowledgements: we acknowledge the financial support of the Decentralization Research Competitive Grant (2014)

Contributions: the authors contributed equally to this work.

Conflict of interest: the authors declare no potential conflict of interest.

Funding: this project was funded by the Decentralization Research Competitive Grant (2014), Ministry of Research and Technology, Directorate of Higher Education, Indonesia.

Received for publication: 2 December 2015 . Revision received: 3 March 2016.

Accepted for publication: 3 March 2016.

This work is licensed under a Creative Commons Attribution-NonCommercial 4.0 International License (CC BY-NC 4.0).

(C) Copyright E.D. Mustikarini et al., 2016

Licensee PAGEPress srl, Italy

International Journal of Plant Biology 2016; 7:6345

doi:10.4081/pb.2016.6345

$\mathrm{M}_{5^{-}}-\mathrm{G}_{\mathrm{R} 10^{-}}-1-4, \quad \mathrm{M}_{5^{-}}-\mathrm{G}_{\mathrm{R} 150^{-}}-1-9, \quad \mathrm{M}_{5^{-}} \mathrm{G}_{\mathrm{R} 150^{-}}-2-2, \quad \mathrm{M}_{5^{-}}$ $\mathrm{G}_{\mathrm{R} 150}-2-3, \mathrm{M}_{5}-\mathrm{G}_{\mathrm{R} 200}-1-2$ and radix accession. The main plot was the soil moisture of $25,50,75$ and 100\% (control). Traits observed were symptoms of rolling, drying of leaves, plant height, number of leaves, the number of tillers, root length, weight of roots, weight of canopy, the number of filled seeds, weight of 1000 seeds, weight of filled seeds, fertility of the grain and the index of drought tolerance trait that calculated by the formula: $S=(1-Y / Y p) /(1-$ $\mathrm{X} / \mathrm{Xp}){ }^{15}$

The third research was drought tolerant trait selection of M6. There were 5 best strain of M6 from the second research. The research was arranged in a split-plot design such as $\mathrm{M}_{5-}$ $\mathrm{G}_{\mathrm{R} 150}-1-4-14, \mathrm{M}_{5}-\mathrm{G}_{\mathrm{R} 150}-1-9-13, \mathrm{M}_{5}-\mathrm{G}_{\mathrm{R} 150}-2-2-2, \mathrm{M}_{5}-$ $\mathrm{G}_{\mathrm{R} 150}-2-3-13, \mathrm{M}_{5}-\mathrm{G}_{\mathrm{R} 200}-1-2-18$ and radix accession. The main plot was the seizing phase of tillering, booting-flowering, seed filling and control. Drought stress was given for 14 days by covering the mutant using plastic. The main traits observed were filled seeds weight. The data of M5 and M6 were analyzed by using Fisher's exact test and least significant difference (LSD) test at the 0.05 level of significance. 


\section{Results and Discussion}

The selection of 1920 lines of M4 red rice paddy with selection intensity of $1.87 \%$ secured 36 of M5 strain. The selected mutant strains derived from Ruten Puren accession with gamma ray irradiation dose of 200 gray, radix irradiation dose of 150 and 200 gray. Mutants derived from the Celak Madu acces- sion of the gamma ray irradiation dose 150 and 250 gray, and Ruten Puren accession dose of 250 gray was unselected of having early ripening traits since it had a harvesting age more than 120 days after planting.

$\mathrm{M}_{4}-\mathrm{G}_{\mathrm{P} 200}-1$ mutant derived from Ruten Puren irradiation gamma ray dose of 200 gray has the lowest harvesting age and highest number of tillers. All mutants have had a similar harvest age (Table 1). These mutants reduced harvest time by 22.81 days earlier than others. Gamma-ray irradiation doses of 150 and 200 gray are effective to gain early maturity mutants. Mutants derived from radix accession reduced harvest time by 17-19 days after irradiation with doses of 150 and 200 gray. Each rice accession has different sensitivity levels.

The M4 results of gamma irradiation have a different character than the previous as shown

Table 1. The selected M4 red rice paddy through pedigree selection.

\begin{tabular}{|c|c|c|c|c|c|c|c|}
\hline N. & $\begin{array}{l}\text { Mutant } \\
\text { name }\end{array}$ & $\begin{array}{c}\text { Age of } \\
\text { harvest } \\
\text { (dap) }\end{array}$ & $\begin{array}{l}\text { Weight of } \\
\text { filled } \\
\text { seeds } \\
\text { (gram) }\end{array}$ & $\begin{array}{l}\text { Number of } \\
\text { filled } \\
\text { seeds } \\
\text { (grain) }\end{array}$ & $\begin{array}{l}\text { Weight of } \\
1000 \\
\text { seeds } \\
\text { (gram) }\end{array}$ & $\begin{array}{c}\text { Number of } \\
\text { tillers } \\
\text { (stems) }\end{array}$ & $\begin{array}{c}\text { Panicle } \\
\text { length } \\
\text { (cm) }\end{array}$ \\
\hline 1 & $\mathrm{M}_{4}-\mathrm{G}_{\mathrm{P} 200}-1-1$ & 110 & 24.28 & 1025 & 23,83 & 12 & 24.0 \\
\hline 2 & $\mathrm{M}_{4}-\mathrm{G}_{\mathrm{P} 200^{-}}-1-2$ & 110 & 23.14 & 886 & 26.12 & 9 & 23.3 \\
\hline 3 & $\mathrm{M}_{4}-\mathrm{G}_{\mathrm{P200}}-1-3$ & 110 & 12.92 & 575 & 22.47 & 10 & 25.5 \\
\hline 4 & $\mathrm{M}_{4}-\mathrm{G}_{\mathrm{P} 200^{-}}-1-4$ & 110 & 16.01 & 648 & 24.71 & 9 & 22.0 \\
\hline 5 & $\mathrm{M}_{4}-\mathrm{G}_{\mathrm{P200}}-1-5$ & 110 & 11.38 & 529 & 21.51 & 8 & 22.0 \\
\hline 6 & $\mathrm{M}_{4}-\mathrm{G}_{\mathrm{P200}}-1-6$ & 110 & 16.59 & 676 & 24.54 & 7 & 22.5 \\
\hline 7 & $\mathrm{M}_{4}-\mathrm{G}_{\mathrm{P200}}-1-7$ & 110 & 18.31 & 665 & 27.53 & 6 & 23.0 \\
\hline 8 & $\mathrm{M}_{4}-\mathrm{G}_{\mathrm{P200}}-1-8$ & 110 & 26.39 & 1038 & 26.07 & 9 & 27.0 \\
\hline 9 & $\mathrm{M}_{4}-\mathrm{G}_{\mathrm{P} 200^{-1}}-9$ & 110 & 23.10 & 884 & 26.13 & 8 & 25.0 \\
\hline 10 & $\mathrm{M}_{4}-\mathrm{G}_{\mathrm{P} 200^{-1}}-10$ & 110 & 15.37 & 660 & 23.29 & 9 & 23.0 \\
\hline 11 & $\mathrm{M}_{4}-\mathrm{G}_{\mathrm{P} 200}-2-1$ & 113 & 14.14 & 805 & 17.57 & 8 & 23.0 \\
\hline 12 & $\mathrm{M}_{4}-\mathrm{G}_{\mathrm{P} 200}-2-2$ & 113 & 18.20 & 621 & 29.31 & 5 & 26.0 \\
\hline 13 & $\mathrm{M}_{4}-\mathrm{G}_{\mathrm{P200}}-4-1$ & 113 & 22.09 & 261 & 24.64 & 5 & 25.0 \\
\hline 14 & $\mathrm{M}_{4}-\mathrm{G}_{\mathrm{P200}}-4-2$ & 113 & 17.95 & 772 & 23.25 & 9 & 25.0 \\
\hline 15 & $\mathrm{M}_{4}-\mathrm{G}_{\mathrm{P} 200}-4-3$ & 113 & 18.44 & 846 & 21.80 & 8 & 24.0 \\
\hline 16 & $\mathrm{M}_{4}-\mathrm{G}_{\mathrm{P} 200}-4-4$ & 113 & 20.42 & 929 & 21.98 & 8 & 25.0 \\
\hline 17 & $\mathrm{M}_{4}-\mathrm{G}_{\mathrm{P} 200}-4-5$ & 113 & 14.83 & 656 & 22.61 & 8 & 19.5 \\
\hline 18 & $\mathrm{M}_{4}-\mathrm{G}_{\mathrm{P} 200}-4-6$ & 113 & 12.10 & 542 & 22.32 & 6 & 23.5 \\
\hline 19 & $\mathrm{M}_{4}-\mathrm{G}_{\mathrm{RI} 50^{-1}}-1$ & 113 & 26.15 & 928 & 28.18 & 8 & 22.0 \\
\hline 20 & $\mathrm{M}_{4}-\mathrm{G}_{\mathrm{R} 150^{-1}}-2$ & 113 & 13.96 & 261 & 53.49 & 6 & 25.0 \\
\hline 21 & $\mathrm{M}_{4}-\mathrm{G}_{\mathrm{RI} 50^{-1}-3}$ & 113 & 18.89 & 761 & 24.82 & 5 & 25.5 \\
\hline 22 & $\mathrm{M}_{4}-\mathrm{G}_{\mathrm{R} 150^{-1}}-4$ & 115 & 19.03 & 781 & 24.37 & 7 & 27.5 \\
\hline 23 & $\mathrm{M}_{4}-\mathrm{G}_{\mathrm{RI} 50^{-1}-5}$ & 115 & 23.69 & 964 & 24.57 & 6 & 29.5 \\
\hline 24 & $\mathrm{M}_{4}-\mathrm{G}_{\mathrm{R} 150^{-1}}-6$ & 112 & 22.64 & 852 & 26.57 & 4 & 22.5 \\
\hline 25 & $\mathrm{M}_{4}-\mathrm{G}_{\mathrm{R} 150^{-1}-7}$ & 112 & 28.17 & 1058 & 26.59 & 8 & 28.0 \\
\hline 26 & $\mathrm{M}_{4}-\mathrm{G}_{\mathrm{R} 150^{-1}-8}$ & 112 & 12.72 & 511 & 24.89 & 7 & 28.5 \\
\hline 27 & $\mathrm{M}_{4}-\mathrm{G}_{\mathrm{R} 150^{-}}-1-9$ & 112 & 27.21 & 1085 & 25.13 & 9 & 27.0 \\
\hline 28 & $\mathrm{M}_{4}-\mathrm{G}_{\mathrm{R} 150^{-}}-1-10$ & 112 & 16.96 & 696 & 24.37 & 6 & 30.0 \\
\hline 29 & $\mathrm{M}_{4}-\mathrm{G}_{\mathrm{R} 150^{-}}-1-11$ & 115 & 32.34 & 1329 & 24.57 & 8 & 26.5 \\
\hline 30 & $\mathrm{M}_{4}-\mathrm{G}_{\mathrm{R} 200^{-1}}-1$ & 112 & 16.22 & 626 & 25.91 & 5 & 26.5 \\
\hline 31 & $\mathrm{M}_{4}-\mathrm{G}_{\mathrm{R} 200^{-1}}-2$ & 112 & 25.75 & 1042 & 24.9 & 5 & 30.0 \\
\hline 32 & $\mathrm{M}_{4}-\mathrm{G}_{\mathrm{R} 200^{-1}}-3$ & 112 & 20.60 & 799 & 25.78 & 7 & 28.0 \\
\hline 33 & $\mathrm{M}_{4}-\mathrm{G}_{\mathrm{RI} 50}-3-1$ & 113 & 16.96 & 637 & 26.62 & 6 & 30.0 \\
\hline 34 & $\mathrm{M}_{4}-\mathrm{G}_{\mathrm{R} 150}-2-1$ & 113 & 13.40 & 588 & 22.79 & 6 & 25.0 \\
\hline 35 & $\mathrm{M}_{4}-\mathrm{G}_{\mathrm{R} 150}-2-2$ & 113 & 15.74 & 630 & 24.98 & 7 & 26.0 \\
\hline 36 & $\mathrm{M}_{4}-\mathrm{G}_{\mathrm{RI} 50}-2-3$ & 113 & 12.44 & 545 & 22.83 & 6 & 23.5 \\
\hline \multicolumn{2}{|c|}{ Ruten Puren sccession } & 134.0 & 18.56 & 1051.2 & 22.00 & 14 & 24.0 \\
\hline \multicolumn{2}{|c|}{ Radix accession } & 130.0 & 12.29 & 649.7 & 22.50 & 5 & 19.5 \\
\hline
\end{tabular}

The criteria selection of harvesting age is more than 115 dap, and the number of extra tillers was 4 stems. 
in Table 1. Mutant varieties originated from South Sulawesi have higher number of tillers, number of filled seeds and higher yield than the previous. Harvesting age of mutant is shorter than previous. ${ }^{11} \mathrm{M} 4$ has a high diversity in their traits of filled seed weight (Table 2). M4 should be further selected so that the weights of produced seeds were more stable. Previous study showed no increase in weight of filled seeds of mutant compared to previous. $^{16}$ Mutants undergo decreasing weight of 1000 seeds.

M4 has shown the character of stable harvesting age with early ripening. An effective dose of gamma ray irradiation for rice is 200300 gray. Mutant harvest time decreased to 52 days at that dose. The higher irradiation dose, it more likely increases the rice emptiness. ${ }^{17}$ The accession of red rice with 150 gray dose of irradiation can actually be used to improve the traits of the plant.

Screening of various stresses can be done to the M4 seed strains. So far, more than 15,000 resulted mutant selections have been distributed and documented. ${ }^{18}$ Early maturity of red rice mutants was associated with drought tolerance traits. It is supported by the 5 selected strain of M5 based on the selection of PEG - 0.5
MPa (equivalent to $15 \%$ moisture) in the germination phase. The selected strains are $\mathrm{M}_{5}$ $\mathrm{G}_{\mathrm{R} 150}-1-4 . \mathrm{M}_{5}-\mathrm{G}_{\mathrm{R} 150}-1-9, \mathrm{M}_{5}-\mathrm{G}_{\mathrm{R} 150}-2-2, \mathrm{M}_{5}-\mathrm{G}_{\mathrm{R} 150}-2$ 3 and $\mathrm{M}_{5}-\mathrm{G}_{\mathrm{R} 200}-1-2$. All of these mutant strains have higher germination rate than the radix accession.

Drought tolerance mutant symptoms were shown by the low leaf rolling and leaf drying. Mutants experience high levels of drought stress on the generative phase. In the generative phase there was an increase in cell volume and the number of sink organs, so the water demand increases. Previous study has managed to select 64 drought-tolerant rice mutants

Table 2. Mean, standard deviation and variance of the Selected M4.

\begin{tabular}{|c|c|c|c|c|c|c|c|}
\hline \multirow[t]{2}{*}{$\begin{array}{l}\text { Selected } \\
\text { mutant (M4) }\end{array}$} & \multirow[t]{2}{*}{ Number of mutant } & \multicolumn{2}{|c|}{$\begin{array}{c}\text { Age of } \\
\text { harvesting (hst) }\end{array}$} & \multicolumn{2}{|c|}{$\begin{array}{c}\text { Number of } \\
\text { tillers (stem) }\end{array}$} & \multicolumn{2}{|c|}{$\begin{array}{c}\text { Weight of } \\
\text { filled seeds (gram) }\end{array}$} \\
\hline & & Mean & $\sigma^{2}$ & Mean & $\sigma^{2}$ & Mean & $\sigma^{2}$ \\
\hline $\mathrm{M}_{4}-\mathrm{G}_{\mathrm{P} 200}-1$ & 10 & $110.00 \pm 0.0$ & 0.00 & $8.70 \pm 1.64$ & 2.68 & $18.75 \pm 5.16$ & 26.58 \\
\hline $\mathrm{M}_{4}-\mathrm{G}_{\mathrm{P} 200}-2$ & 2 & $113.00 \pm 0.0$ & 0.00 & $6.50 \pm 2.12$ & 4.50 & $16.17 \pm 2.87$ & 8.24 \\
\hline $\mathrm{M}_{4}-\mathrm{G}_{\mathrm{P} 200}-4$ & 6 & $113.00 \pm 0.0$ & 0.00 & $7.33 \pm 1.51$ & 2.27 & $17.64 \pm 3.66$ & 13.37 \\
\hline $\mathrm{M}_{4}-\mathrm{G}_{\mathrm{R} 150^{-}}-1$ & 11 & $113.09 \pm 1.3$ & 1.69 & $6.73 \pm 1.49$ & 2.22 & $21.98 \pm 6.22$ & 38.73 \\
\hline $\mathrm{M}_{4}-\mathrm{G}_{\mathrm{R} 150}-2$ & 3 & $113.00 \pm 0.0$ & 0.00 & $6.33 \pm 0.58$ & 0.33 & $13.86 \pm 1.70$ & 2.88 \\
\hline $\mathrm{M}_{4}-\mathrm{G}_{\mathrm{R} 150}-3$ & 1 & $113.00 \pm 0.0$ & 0.00 & $6.00 \pm 0.00$ & 0.00 & $16.96 \pm 0.00$ & 0.00 \\
\hline$\underline{\mathrm{M}_{4}-\mathrm{G}_{\mathrm{R} 200^{-}}-1}$ & 3 & $112.00 \pm 0.0$ & 0.00 & $5.67 \pm 1.15$ & 1.33 & $20.86 \pm 4.77$ & 22.75 \\
\hline
\end{tabular}

$\sigma^{2}=$ variance

Table 3. Scrolling, drying and mutants death (M5) percentage to a few test of soil moisture (\%).

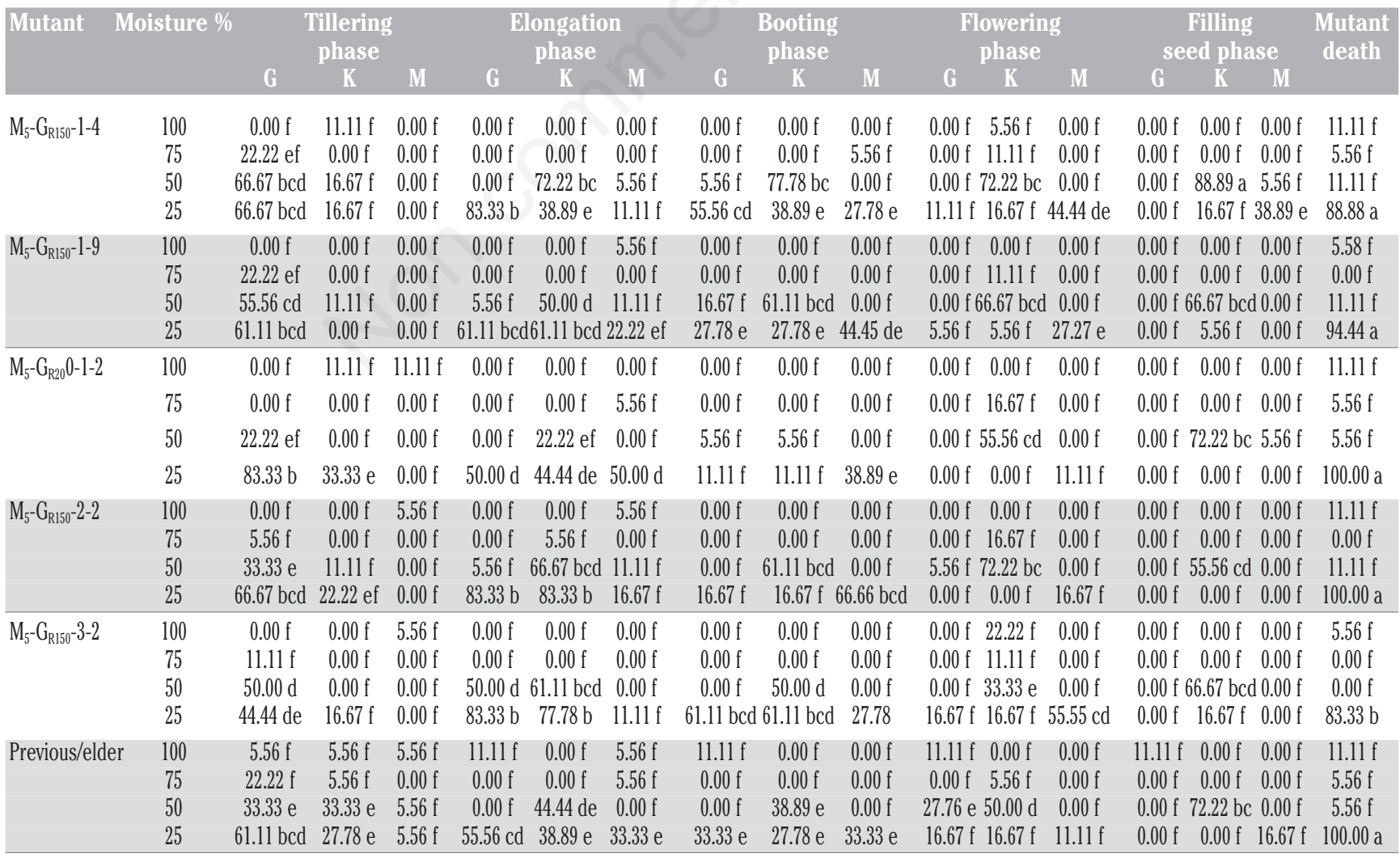

LT, Soil Moisture; G, Symptoms of Scrolling Leaves; K, Symptopms of Drying Leaves; M, Death Plant. Based on field observations, the red rice mutant enter the phase of tillering at the age of 28-42 dap (day of planting/hts (hari setelah tanam), elongation phase at 43-70 dap, the phase of panicle formation and gestation at the age 70-77 dap, flowering phase of 77-91 dap, while the phase of seed filling >91 hst/dap.The same notation means no significant, different notation means significant. 
using the characters of scrolling leaves. ${ }^{13}$ Leaf rolling and leaf drying were correlated negatively to the rice yields. ${ }^{19}$ However, in mutants, it was correlated to the number of empty seed, resulting in lower yield. Symptoms of drought stress is the rolled leaves, dried leaves, delayed booting and imperfect seed filling. ${ }^{20}$ Rice, which is sensitive to drought, has higher leaf rolling score. ${ }^{21}$ Leaf rolling is used to determine drought tolerance of rice. Mutants with the lowest percentage of leaf rolling are more drought-tolerant.

Scrolling leaves of mutants led to leaf drying in flowering phase. The highest numbers of drying leaves were on $\mathrm{M}_{5}-\mathrm{G}_{\mathrm{R} 150^{-1}}-4$ and $\mathrm{M}_{5-}$ $\mathrm{G}_{\mathrm{R} 150}-2-2 . \mathrm{M}_{5}-\mathrm{G}_{\mathrm{R} 150}-2-3$ was the most drought tolerance mutants (Table 3). Critical period of mutants in the vegetative phase is tillering stage. Generative phase occurs with the increasing number of mutants, which experienced leaf drying and death. Mutants on 25\% soil moisture have experienced death in insemination and flowering phases. Mutants on $100 \%$ soil moisture were dead due to low soil aeration and high amount of water, which tied the clay fraction. Planting on ultisols medium has low porosity due to clay content which reached $40.20 \%$.

Drying leaves is a sign of mutant experience high drought stress. Drought stress on insemination and seed filling phase causes a higher decrease in yield. Drought caused reduction in the distribution and allocation of dry matter, the reduction of photosynthetic capacity as a result of closing of stomata, inhibition of metabolism and damage to the chloroplast. ${ }^{22} \mathrm{~A}$ previous study shows that lack of water in the reproductive phase decreases the amount of panicles and increased sterility. ${ }^{23}$ Drought stress at 3 weeks before harvest degrades chlorophyll so that it lowers the rate of photosynthesis. $\mathrm{M}_{5}-\mathrm{G}_{\mathrm{R} 150^{-}}-1-9$ and $\mathrm{M}_{5}-\mathrm{G}_{\mathrm{R} 150^{-}}-2-3$ experience the lowest drying leaves stress in grain filling phase. Both of M5 strains were more drought-tolerant to the other mutant.
Low symptoms of drying leaf were on $\mathrm{M}_{5^{-}}$ $\mathrm{G}_{\mathrm{R} 150}-2-3$ and $\mathrm{M}_{5}-\mathrm{G}_{\mathrm{R} 150}-1-9$. Low symptoms of leaf drying M5-GR150-2-3 and M5-GR150-1-9 correlated with a lower index value tolerance (IST) (Table 4). Both mutants were more drought-tolerant than other mutants and previous. Genotypes with low IST indicated drought tolerant. ${ }^{19}$ Upland rice mutant superiority has the higher number of grains per panicle, an early ripening age and harvesting, larger seed size and form shape red purplish rice (forming anthocyanin). ${ }^{24}$

The increase of drought-tolerant traits of the mutant compared with radix accession aside from indication by the value of IST is also demonstrated by filled seed weight/clump. M5 and M6's filled seeds weighs are higher than
Radix accession. The highest average of filled seed weight is $\mathrm{M}_{5}-\mathrm{G}_{\mathrm{R} 150}-1-9$. The mutant is more tolerant to drought than other mutants and radix accession to the decrease in $75 \%$ of soil moisture. $M_{6}-G_{R 150}-1-9-13$ strain, which is a descendant of the $\mathrm{M}_{5}-\mathrm{G}_{\mathrm{R} 150}-1-9$, also had a high average weight of filled seeds. $\mathrm{M}_{6}-\mathrm{G}_{\mathrm{R} 150}-1-9-13$ strain has the highest weight of filled seeds in drought stress in tillering stage (Figure 1). The number of filled seeds per panicle is positively correlated with yield. ${ }^{25}$ M5 and M6 strains, which have higher weight of filled seeds also have a high yield. The results show that the improvement of early maturity traits through gamma ray irradiation may form drought-tolerant trait of mutant red rice and increase crop yields.

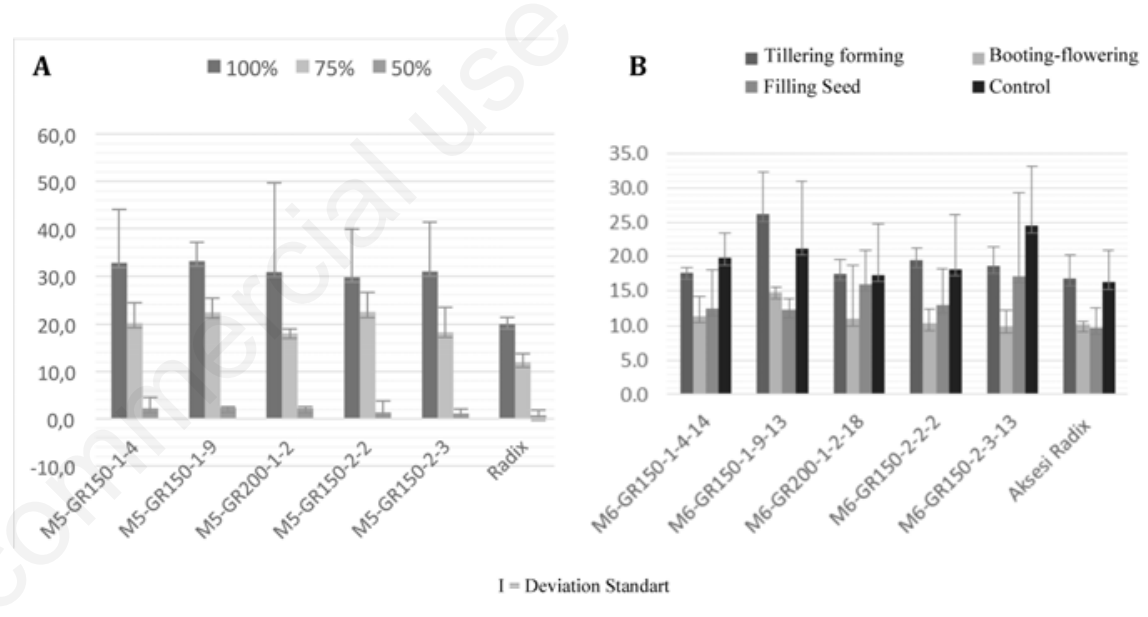

Figure 1. The mean weight of M5 filled seeds (A), M6 filled seeds (B) and radix accession to the treatment of several drought tolerance soil moisture test and drought stress in the critical period of the plant.

Table 4. M5 tolerance and radix accession to the decline of $75 \%$ soil moisture.

\begin{tabular}{|c|c|c|c|c|c|c|}
\hline \multirow[t]{2}{*}{ Plant traits } & \multicolumn{5}{|c|}{ Mutant and Previous/Elder } & \multirow{2}{*}{$\begin{array}{c}\text { Radix } \\
\text { accessions }\end{array}$} \\
\hline & $\mathrm{M}_{5}-\mathrm{G}_{\mathrm{R} 150^{-}}-1-4$ & $\mathrm{M}_{5}-\mathrm{G}_{\mathrm{R} 150}-1-9$ & $\mathrm{M}_{5}-\mathrm{G}_{\mathrm{R} 200}-1-2$ & $\mathrm{M}_{5}-\mathrm{G}_{\mathrm{R} 150}-2-2$ & $\mathrm{M}_{5}-\mathrm{G}_{\mathrm{R} 150-2-3}$ & \\
\hline Plant height & $1.00 \mathrm{p}$ & $1.01 \mathrm{p}$ & $1.04 \mathrm{p}$ & $0.95 \mathrm{~m}$ & $1.00 \mathrm{p}$ & $0.97 \mathrm{~m}$ \\
\hline Number of leaves & $1.03 \mathrm{p}$ & $0.98 \mathrm{~m}$ & $0.96 \mathrm{~m}$ & $0.95 \mathrm{~m}$ & $0.93 \mathrm{~m}$ & $1.08 \mathrm{p}$ \\
\hline Number of tillers & $1.03 \mathrm{p}$ & $0.9 \mathrm{~m}$ & $1.21 \mathrm{p}$ & $0.77 \mathrm{~m}$ & $0.78 \mathrm{~m}$ & $1.33 \mathrm{p}$ \\
\hline Root length & $1.03 \mathrm{p}$ & $0.9 \mathrm{~m}$ & $1.02 \mathrm{p}$ & $0.88 \mathrm{~m}$ & $1.08 \mathrm{p}$ & $1.09 \mathrm{p}$ \\
\hline Root weight & $0.62 \mathrm{~m}$ & $0.89 \mathrm{~m}$ & $1.97 \mathrm{p}$ & $0.77 \mathrm{~m}$ & $0.62 \mathrm{~m}$ & $2.64 \mathrm{p}$ \\
\hline Crown weight & $0.94 \mathrm{~m}$ & $0.97 \mathrm{~m}$ & $1.13 \mathrm{p}$ & $0.93 \mathrm{~m}$ & $0.86 \mathrm{~m}$ & $1.2 \mathrm{p}$ \\
\hline Number of filled seed & $0.99 \mathrm{~m}$ & $0.97 \mathrm{~m}$ & $1.02 \mathrm{p}$ & $1.12 \mathrm{p}$ & $0.92 \mathrm{~m}$ & $0.97 \mathrm{~m}$ \\
\hline Weight of 1000 seeds & $1.17 \mathrm{p}$ & $1.5 \mathrm{p}$ & $1.51 \mathrm{p}$ & $1.53 \mathrm{p}$ & $0.44 \mathrm{t}$ & $\_0.1 \mathrm{p}$ \\
\hline Weight of filled seeds & $1.05 \mathrm{p}$ & $0.89 \mathrm{~m}$ & $1.14 \mathrm{p}$ & $0.67 \mathrm{~m}$ & $1.13 \mathrm{p}$ & $1.12 \mathrm{p}$ \\
\hline Filled seed grain & $1.03 \mathrm{p}$ & $0.91 \mathrm{~m}$ & $1.02 \mathrm{p}$ & $1.09 \mathrm{p}$ & $1.05 \mathrm{p}$ & $0.88 \mathrm{~m}$ \\
\hline
\end{tabular}

Index tolerance; t, tolerant $<0.5$; m, medium $0.5-1 ; \mathrm{p}$, sensitivity $>1 .^{15}$ 
2009;57:96-102.

\section{Conclusions}

Gamma-ray irradiation dose of 150 and 200 gray on Bangka local red rice paddy accession can form mutant, which has the characteristics of early maturity, drought tolerant and higher yield than the previous. $\mathrm{M}_{6}-\mathrm{G}_{\mathrm{R} 150}-1-9-13$ strain was selected as a candidate for early maturity, drought tolerant and high-yielding mutant.

\section{References}

1. Suliartini NWS, Sadimantara GR, Wijayanto T. Pengujian kadar antosianin padi gogo beras merah hasil koleksi plasma nutfah Sulawesi Tenggara. Crop Agro 2011;4:43-8.

2. Sutharut J, Sudarat J. Total anthocyanin content and antioxidant activity of germinated colored rice. Int Food Res J 2012;19:215-21.

3. Utami DW, Hanarida I. Karakter spesifik plasma nutfah padi beras warna. Warta Biogen 2009;5:11-2.

4. Angraini T, Novelina UL, Amelia R. Antioxidant activities of same red, black and white rice cultivar from West Sumatera, Indonesia. Pakistan J N 2015;14:112-7.

5. Sanghera GS, Kashyap SC, Parray GA. Genetic variation for grain yield and related traits in temperate red rice (Oryza sativa L.) ecotypes. Natulae Biologiane 2013;5:400-6.

6. Shivrain VK, Burgos NR, Gealy DR, et al. Red rice (Oryza sativa) emergence characteristics and influence on rice yield at different planting dates. Weed Sci
7. Aryana IGPM. Adaptasi dan stabilitas hasil galur-galur padi beras merah pada tiga lingkungan tumbuh berbeda. J Agron Indonesia 2009;37:95-100.

8. Agriculture Research and Development Department. Inpago 7 Beras Merah Padi Gogo. No. 3464; 2012.

9. Prasetiyono J, Moeljopawiro S, Taslia. Observasi daya hasil galur-galur padi turunan code dan ciherang berumur genjah dan produksi tinggi hasil mab. Rep Res Technol Min Indon 2012.

10. Degenkolbe T, Do PT, Zuther E, et al. Expression profiling of rice cultivars differing in their tolerance to long-term drought stress. Plant Mol Biol 2009;69:13353.

11. Haris A, Abdullah, Baktiar, et al. Gamma ray radiation mutant rice on local aged dwarf. Middle East J Sci Res 2013;15:11604.

12. Chongkid B. Gamma-ray induced mutation of KDML105 for photo insensitivity, short harvest age and drought tolerance. Am Trans Eng Appl Sci 2013;2:269-75.

13. Hallajian MT, Ebadi AA, Mohammadi M, et al. Integration on mutation and conventional breeding approaches to develop new superior drought- tolerance plants in rice. Ann Res Rev Biol 2014;4:1173-85.

14. Swain P, Anumalla M, Prusty S, et al. Characterization of some Indian native land race rice accession for drought tolerance at seeding stage. Aust J Crop Sci 2014;8:324-31.

15. Fischer RA, Maurer R. Drought resistance in spring wheat cultivar. I grain yield response. Aust J Agric Res 1978;29:897-12.

16. Domigo C, Andres F, Talon M. Rice Cv Bahia mutagenized population: a new resource for rice breeding in the
Mediterranean basin. Span J Agric Res 2007;5:341-47.

17. Sulistiansyah I. Perbaikan padi lokal Sumatera Barat melalui pemuliaan mutasi. Proceedings of the National Conference Agriculture Reformation Integrated to Food Sovereignity, 2011 Oct 20, Trunojoyo University, Indonesia. pp 111.

18. Wu JL, Wu C, Lei C, et al. Chemical- and irradiation-induced mutants of indica rice IR64 for forward and reverse genetics. Plant Mol Biol 2005;59:85-97.

19. Kumar S, Dwivedi SK, Singh SS, et al. Identification of drought tolerant rice genotypes by analysing drought tolerance indices and morpho-physiological traits. Sabrao J Breed Genet 2014;46:217-30.

20. Yosida S. Fundamental of rice crop science, Los Banos: Internasional Rice Research Institute; 1981.

21. Ji K, Wang Y, Sun W, et al. Drought-responsive mechanisms in rice genotypes with contrasting drought tolerance during reproductive stage. J Plant Physiol 2012; 169:336-44.

22. Farooq M, Wahid A, Kobayasin N, et al. Plant drought stress: effects, mechanisms and management. Agron Sustain Dev 2009;29:185-12.

23. Maisura, Chozin MA, Lubis I, et al. Some physiological character responses of rice under drought conditions in a paddy system. Int Soc Southeast Asian Agric Sci 2014;20:104-14.

24. Ishak. Sifat agronomis, heritabilitas dan interaksi $\mathrm{g} \mathrm{x}$ e galur mutan padi gogo. J Agron Indonesia 2012;40:105-11.

25. Das P, Mukherjee B, Santra CK, et al. Agrobotanical characterization of some released F1 hybrids in rice (Oryza sativa L.). Int J Sci Res Publ 2014;4:1-8. 